\title{
INTERDEPENDENSI STRATEGI PEMASARAN \\ TERHADAP KINERJA PERUSAHAAN \\ (Suatu Penelitian pada Perusahaan Asuransi Indonesia yang sudah go public)
}

\author{
Cecep Hidayat; Iskandar Putong; Rini Kurnia Sari \\ Management Department, School of Business Management, BINUS University \\ Jln. K.H. Syahdan No. 9, Palmerah, Jakarta Barat 11480 \\ ceceph1267@binus.ac.id; xanderputong@gmail.com; rini_kurnia_sari@yhoo.com
}

\begin{abstract}
This study aims to analyze the interdependence between the variables of marketing strategy and organizational performance of insurance companies using canonical correlation analysis with multiple multivariate analysis approach. The interdependent correlation value may explain the subgroup which the dominant variable affects other subgroups on the company based on the value of redundancy index. The study population was 9 go public insurance companies when the study was conducted in 2013. Given two exogenous variables, i.e. variables Effectiveness Strategy (STRAEFEK) and Efficiency Strategy (STRATEFIS). Endogenous variable is the Debt to Asset Ratio (DAR), Debt to Eqiity Ratio (DER), Return on Assets (ROA), Return on Equity (ROE), Operating Profit Margin (OPM) and Net Profit Margin (NPM).
\end{abstract}

Keyword: interdependence, effectiveness strategy, efficiency strategy, company performance

\begin{abstract}
ABSTRAK
Penelitian bertujuan untuk menganalisis interdependensi antara variabel strategi pemasaran dan kinerja organisasional perusahaan asuransi menggunakan analisis korelasi kanonik dengan pendekatan analisis multiple multivariate. Nilai korelasi yang bersifat interdependensi tersebut dapat menjelaskan variabel subkelompok mana yang dominan memengaruhi subkelompok lainnya pada perusahaan berdasarkan nilai redundancy index. Populasi penelitian adalah 9 perusahaan asuransi yang sudah go public pada saat penelitian dilakukan (2013). Dua variabel exogen diketahui, yaitu variabel Strategi Efektivitas (STRAEFEK) dan Strategi Efisiensi (STRATEFIS). Variabel endogen adalah rasio hutang terhadap aset (DAR), rasio modal terhadap aset (DER), Return on Asset (ROA), Return on Equity (ROE), Operating Profit Margin (OPM) dan Net Profit Margin $(N P M)$.
\end{abstract}

Kata kunci: interdependensi, strategi efektivitas, strategi efisiensi, kinerja perusahaan 


\section{PENDAHULUAN}

Dunia usaha bersifat dinamis; selalu mengalami perubahan yang terjadi setiap saat dan ada keterkaitan antara satu dengan yang lain. Oleh karena itu, strategi pemasaran mempunyai peranan yang sangat penting untuk keberhasilan perusahaan umumnya dan bidang pemasaran khususnya. Untuk menjalankan kegiatan pemasaran tersebut dengan baik, dan sesuai dengan sasaran yang diharapkan, perusahaan harus menerapkan suatu strategi yang tepat sesuai dengan lingkungan pemasaran perusahaan.

Strategi pemasaran yang diterapkan oleh sebuah perusahaan pada akhirnya akan bermuara atau berhubungan pada kinerja organisasional (Jaakkola, et al, 2010; Hopper, T., 2006; Koksal \& Ozgul, 2007; dan Neill S., \& Rose G.M., 2006). Sebagian besar artikel jurnal yang dijadikan referensi secara metodologis tidak menganalisis lebih mendalam sifat interdependensi antara variabel-variabel pembentuk tersebut. Demikian juga penelitian-penelitian tersebut tidak menentukan apakah manifestasi variabel tersebut bersifat pembentuk (formatif) atau sekadar cerminan (reflektif).

Kinerja organisasional merupakan akibat ataupun penyebab yang diharapkan meningkat berkaitan dengan implikasi dan aplikasi strategi pemasaran. Akibat (dependent) atau penyebab (independent) dalam hal ini merupakan hal yang memang tidak mudah ditentukan: apakah akibat, penyebab, atau keduanya. Berkaitan dengan hal tersebut, penelitian tertarik untuk menganalisis interdependensi antara variabel strategi pemasaran dan kinerja organisasional perusahaan asuransi, khususnya perusahaan asuransi di Indonesia yang sudah go public (tbk). Di samping itu, sifat hubungan dari manifestasi masing-masing variabel strategi dan kinerja menjadi rencana kajian dalam penelitian ini.

Penelitian ini diharapkan dapat mengembangkan suatu model hubungan strategi pemasaran dengan kinerja keuangan perusahaan. Sehingga pada akhirnya model tersebut dapat menggambarkan sifat hubungan antara unsur-unsur dari strategi pemasaran korporasi yang berdampak secara signifikan pada kinerja perusahaan asuransi di Indonesia.

\section{Faktor-faktor yang Memengaruhi Strategi Pemasaran}

Strategi pemasaran hendaknya mempertimbangkan situasi dan keadaan perusahaan baik keadaan intern perusahaan atau lingkungan mikro perusahaan maupun keadaan ekstern perusahaan atau yang dikenal dengan lingkungan makro perusahaan. Faktor-faktor yang dapat memengaruhi strategi pemasaran pada suatu perusahaan adalah lingkungan mikro dan lingkungan makro. Lingkungan mikro adalah lingkungan internal yang bisa merupakan kekuatan dan sekaligus juga kelemahan. Lingkungan makro merupakan lingkungan eksternal yang kesempatan-kesempatan bisa diperoleh dan tantangan-tantangan yang mungkin akan dihadapi.

Lingkungan mikro perusahaan terdiri dari para pelaku dalam lingkungan yang langsung berkaitan dengan perusahaan yang mempengaruhi kemampuannya untuk melayani pasar, yaitu antara lain: perusahaan, pemasok, para perantara pemasaran, para pelanggan, para pesaing, dan masyarakat umum. Sementara lingkungan makro terdiri dari kekuatan-kekuatan yang bersifat kemasyarakatan yang lebih besar dan memengaruhi semua pelaku dalam lingkungan mikro dalam perusahaan. Adapun lingkungan makro terdiri dari lingkungan demografis/kependudukan, lingkungan ekonomi, lingkungan fisik, lingkungan teknologi, dan lingkungan sosial/budaya.

Strategi pemasaran adalah pengambilan keputusan-keputusan tentang biaya pemasaran, bauran pemasaran, alokasi pemasaran dalam hubungan dengan keadaan lingkungan yang diharapkan dan kondisi persaingan. Henry Mintzberg mendefinisikan strategi sebagai 5P, yaitu: strategi sebagai 
perspectif, strategi sebagai posisi, strategi sebagai perencanaan, strategi sebagai pola kegiatan, dan strategi sebagai penipuan (ploy) yaitu muslihat rahasia. Sebagai perspektif, strategi dalam membentuk misi; misi menggambarkan perspektif kepada semua aktivitas. Sebagai posisi, strategi mencari pilihan untuk bersaing. Sebagai perencanaan, dalam hal strategi menentukan tujuan performa perusahaan. Sebagai pola kegiatan, dalam strategi dibentuk suatu pola, yaitu umpan balik dan penyesuaian.

Strategi pemasaran yang diterapkan oleh suatu perusahaan harus disesuaikan tidak hanya pada sasaran konsumen semata, tetapi juga pada para pesaing yang mengincar pasar sasaran konsumen yang sama. Perusahaan sebelum menetapkan dan menjalankan strateginya pada umumnya terlebih dahulu malakukan analisis SWOT (Strength, Weakness, Opportunity, and Threat), yaitu melihat dan menganalisis kekuatan, kelemahan, peluang, dan ancaman yang dimiliki dan juga yang dimiliki para pesaingnya.

\section{Strategi Berdasarkan Penguasaan Pasar}

Strategi bersaing bergantung pada besar dan posisi masing-masing perusahaan dalam pasar. Perusahaan besar mampu menerapkan strategi tertentu, yang jelas tidak bisa dilakukan oleh perusahaan kecil. Akan tetapi, skala besar tidaklah cukup karena ada beberapa strategi bagi perusahaan besar yang mampu menjamin keberhasilannya namun ada juga strategi yang dapat merugikan diri sendiri. Bukanlah merupakan sesuatu hal yang jarang terjadi bahwa perusahaan kecil dengan strateginya sendiri mampu menghasilkan tingkat keuntungan yang sama atau bahkan lebih baik daripada yang diperoleh perusahaan besar. Sehubungan dengan besarnya usaha, kelompok usaha dapat dibedakan menjadi market leader, market challenger, market follower, dan market nicher. Masing-masing kelompok usaha memiliki alternatif strategi yang berbeda satu sama lain.

\section{Unsur-unsur Staregi Pemasaran}

Strategi pemasaran terdiri dari beberapa unsur yang saling terkait. Yang pertama dan paling penting adalah memilih pasar yang akan dilayani. Setelah itu, unsur yang tidak kalah penting adalah perencanaan produk. Perencanaan produk meliputi spesifikasi dari produk yang akan dijual, susunan dari produk dan desain penawaran secara individu. Unsur lainnya adalah sistem distribusi, penjualan secara grosir dan eceran produk yang akan dipasarkan dan akhirnya jatuh ke tangan konsumen. Strategi pemasaran selanjutnya adalah strategi komunikasi dengan menggunakan iklan untuk menginformasikan kepada pelanggan potensi kegunaan dari produk tersebut melalui radio, televisi, email, dan brosur dan personal selling. Strategi tersebut bertujuan untuk mempromosikan produk kepada pelanggan supaya akhirnya pelanggan tertarik dan membeli produk tersebut. Harga merupakan unsur yang penting dari setiap program pemasaran yang dilakukan perusahaan. Selain itu merek dari produk juga merupakan unsur penting dari sebuah strategi pemasaran yang berhasil. Sebuah perusahaan mungkin harus memilih antara menggunakan nama keluarga sebagai merek atau nama yang berbeda.

Penekanan pada unsur-unsur atau aspek-aspek tertentu dari strategi pemasaran akan sangat bervariasi, bahkan di antara kompetitor yang menjual produk yang sama dan memiliki target market yang sama dengan perusahaan. Penekanan terhadap aspek-aspek tertentu tersebut akan bergeser juga, dari waktu ke waktu sesuai dengan perubahan kondisi pasar yang ada. Dengan memerhatikan unsurunsur penting tersebut dalam menjalankan strategi marketing, perusahaan akan meningkatkan nilai jual yang lebih lagi dan profit yang signifikan.

\section{Kinerja Organisasional}

Kinerja organisasional menggambarkan sampai seberapa jauh organisasi tersebut mencapai hasil ketika dibandingkan kinerja terdahulu dengan organisasi lain dan sampai seberapa jauh pencapaian tujuan dan target yang telah ditetapkan. Kinerja sebuah organisasi secara umum dapat 
dibagi dua yaitu kinerja finansial dan kinerja nonfinansial. Aspek finansial walaupun mengandung beberapa kelemahan, hal tersebut merupakan aspek yang paling umum dan paling sering digunakan untuk mengukur sebuah kinerja organisasi/perusahaan. Demikian juga dalam penelitian ini mengingat kaitan dengan ketersediaan data kinerja keuangan dijadikan ukuran kinerja perusahaan asuransi.

Ketidakefisienan sebuah perusahaan yang sering kali dijadikan sebagai tolok ukur adalah kinerja keuangan. Cara yang paling sering digunakan dalam mengukur kinerja organisasi adalah mennujukkan hasilnya dalam penerimaan (revenues), biaya (cost), dan profitabilitas (profitability). Adapun indikator kinerja keuangan yang dijadikan tolok ukur dalam penelitian ini adalah rasio keuangan sebagai berikut: dividend, EPS (Earning per Share), BP (Basis Point value), DAR (Debt to Asset Ratio), DER (Debt to Equity Ratio), ROA (return On Asset), ROE (Return On Equity), OPM (Operating Profit Margin), NPM (Net Profit Margin), Pay Out Ratio.

\section{Hubungan antara Strategi pemasaran dan Kinerja Organisasi}

Penelitian Jaakkola, et al (2010), seperti tergambar dalam model pemikiran (Gambar 1), mengimplikasikan hubungan antara strategi pemasaran dengan kinerja organisasi. Penelitian tersebut menyimpulkan terdapat hubungan yang signifikan antara variabel manifest strategic marketing dengan business performance sebagai manifest dari company success. Sifat hubungan antara kedua variabel tersebut (strategic marketing and company success) saling memengaruhi seperti terlihat dari arah kedua panah dalam model.

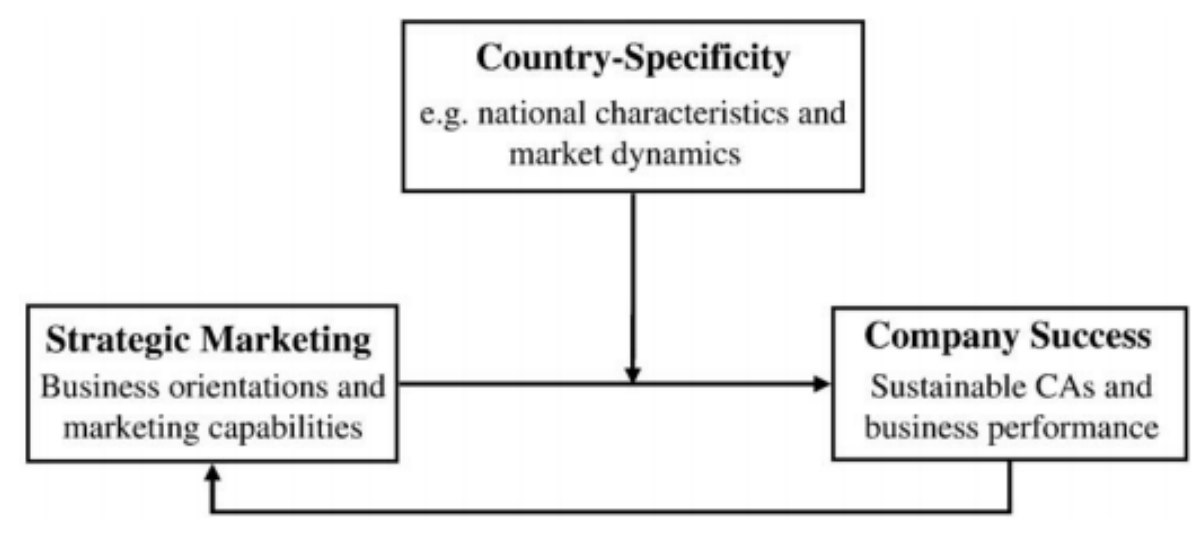

Gambar 1 Kerangka Penelitian: Strategic Marketing dan Business Performance (Sumber: Jaakkola, et al, 2010)

Penelitian lain yang menujukkan bahwa strategi pemasaran berpengaruh secara signifikan adalah penelitian dari Koksal dan Ozgul (2007) menyatakan bahwa terdapat hubungan variabel unsurunsur strategi pemasaran (General marketing strategy, Product strategy, Pricing strategy, Promotion strategy, dan "Place" strategy) dengan kinerja perusahaan (Sales, Market share, Net profit). Penelitian lain yang berkaitan dengan hubungan antara startegi pemasaran dan kinerja organisasi yang cukup relevan karena adalah penelitian dari Hopper (2006) yang meneliti tentang keterkaitan antara organisational strategy, marketing strategy, dan organisational performance. Hopper (2006) memfokuskan penelitian pada hubungan antara proses strategi pemasaran (formulation, implementation, dan evaluation) terhadap keberlanjutan kinerja organisasional. Secara lebih terperinci model yang diusulkan oleh Hopper adalah seperti terlihat pada Gambar 2. 


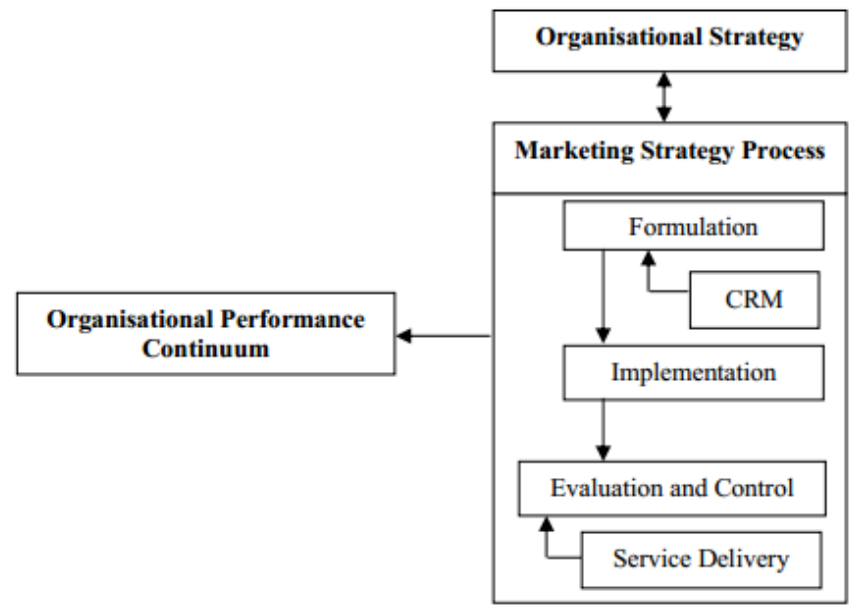

Gambar 2 A conceptual model of organisational strategy, marketing strategy, and organisational performance in regional Queensland public and private hospitals

(Sumber: Hopper, 2006)

Penelitian lain yang senada (memberikan penekanan pada proses strategi) dengan penelitian Hopper (2006) yaitu penelitian dari Neill dan Rose (2006) yang meneliti tentang kompleksitas startegis yang berpengaruh terhadap kinerja organisasional dan proses strategi pemasaran. Yang membedakan keduanya adalah sifat arah hubungan antara dimensi atau manifestasi dari variel-variabel tersebut. Secara lebih terperinci arah hubungan variabel dari penelitian Neill dan Rose (2006) dapat dilihat dari Gambar 3.

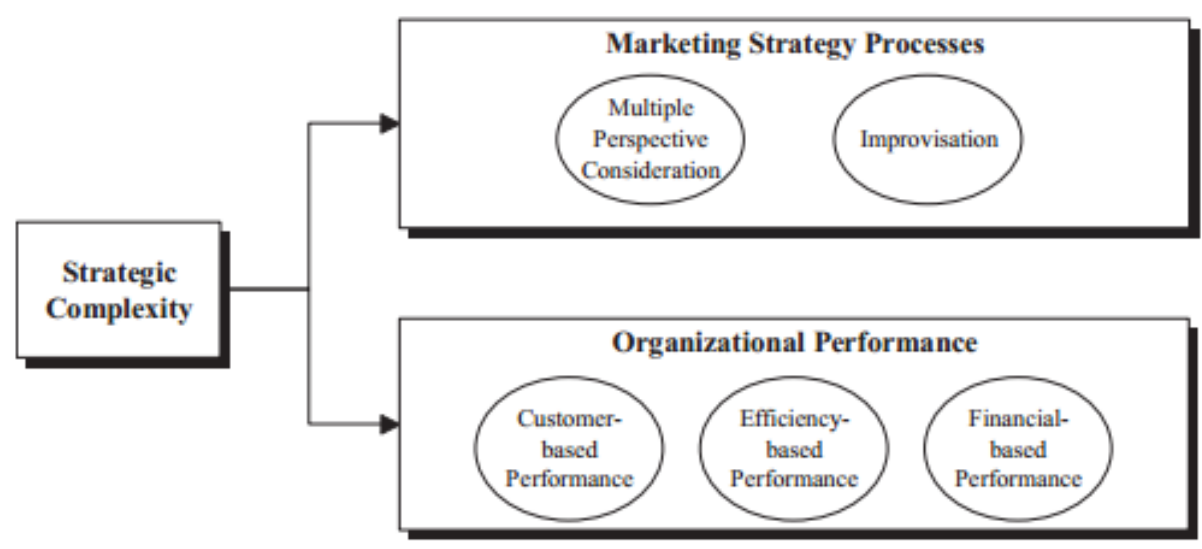

Gambar 3 The Effects of strategic complexity on marketing strategy processes and organizational performance (Sumber: Neill \& Rose, 2006)

\section{Kerangka Teoretis Alur Pikir}

Seperti telah dibahas dalam kajian teoretis, dari beberapa teori unsur stratregi pemasaran pada umumnya terdapat enam kategori strategi dasar yang dapat diterapkan pada masing-masing unit bisnis sebuah korporasi, yaitu: (1) strategi pasar (market strategies), (2) strategi produk (product strategies), (3) strategi manajemen dan sistem (management and system strategies), (4) strategi teknologi (technology strategies), (5) strategi penghematan (retrenchment strategies), (6) strategi operasi (operation strategies). Berdasarkan hasil penelitian sebelumnya (Hibah Binus tahap 1) yang dilakukan 
oleh peneliti, keenam strategi pemasaran tersebut dapat dikelompokkan dalam dua kategori utama yaitu strategi efektivitas dan strategi efisiensi dengan rentangan efektivitas dan efisiensi tertentu. Dari rentangan tersebut pada akhirnya diperoleh fakta perusahaan asuransi mana yang masuk ke masingmasing kelompok rentangan (efisien, cukup efisien, dan tidak efisien). Demikian juga untuk kategori efektivitas dapat diidentifikasi perusahaan-perusahan mana yang masuk ke kelompok rentangan (efektif, cukup efektif, dan tidak efektif).

Variabel kinerja teori yang digunakan adalah kinerja yang paling umum dan sering digunakan karena ketersedian data untuk kinerja tersebut lebih mudah diperoleh. Adapun indikator kinerja finansial tersebut adalah Debt to Asset Ratio (DAR), Debt to Equity Ratio (DER), Return On Asset (ROA), Return On Equity (ROE), Operating Profit Margin (OPM), Net Profit Margin (NPM). Selanjutnya dengan menggunakan analisis canonical correlation pendekatan multiplemultivariate analysis yang terbentuk, terlihat hubungan interdependensi antara kedua variabel utama penelitian. Nilai korelasi yang bersifat interdependensi tersebut dapat menjelaskan variabel subkelompok mana yang dominan memengaruhi subkelompok lainnya pada perusahaan berdasarkan nilai redundancy index.

Adapun paradigma /model penelitian serta perkiraan hubungan antara variabel secara hipotetik secara lebih terperinci dapat dilihat dari Gambar 4 berikut.

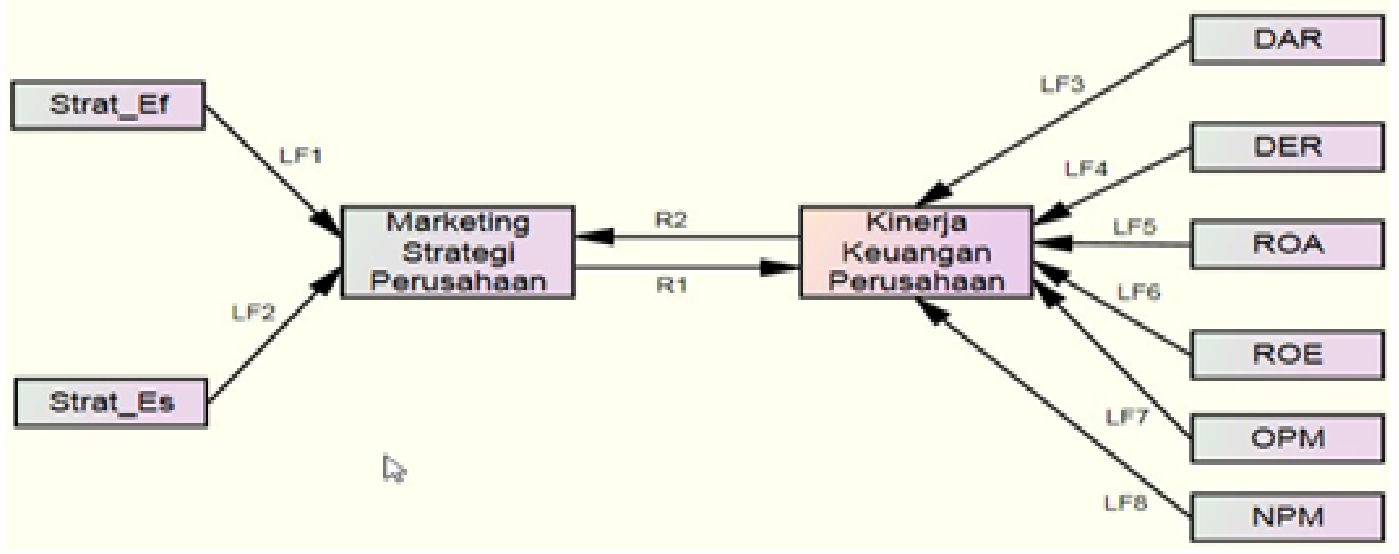

Gambar 4 Paradigma Penelitian

Keterangan :

$\begin{array}{ll}\text { Strat_Ef } & \text { : Strategi Efektivitas } \\ \text { Strat_Es } & \text { : Stretegi Efisiensi } \\ \text { LF 1-8 } & \text { : Loading Factor } \\ \text { R1-2 } & \text { : Redundancy Index } \\ \text { DAR } & \text { : Debt to Asset Ratio, } \\ \text { DER } & \text { : Debt to Equity Ratio } \\ \text { ROA } & \text { : Return On Asset, } \\ \text { ROE } & \text { : Return On Equity } \\ \text { OPM } & \text { : Operating Profit Margin } \\ \text { NPM } & \text { : Net Profit Margin }\end{array}$




\section{METODE}

\section{Jenis Penelitian dan Teknik Pengambilan Sampel}

Fokus utama penelitian adalah menganalisis variabel-variabel strategi terhadap kinerja keuangan perusahaan. Sesuai dengan maksud dan tujuan penelitian sebagaimana yang dikemukakan, jenis penelitian yang digunakan dalam penelitian ini adalah penelitian eksplanatori (eksplanatory research). Beberapa tujuan penelitian eksplanatori antara lain menentukan keakuratan teori, menguji prediksi teori atau prinsip, membangun dan menguraikan teori, memperkaya prediksi teori atau prinsip, mengembangkan sebuah teori atau prinsip ke daerah baru, masalah baru, dan topik-topik baru, dan memberikan bukti untuk mendukung atau menolak penjelasan atau prediksi (Jogiyanto, 2004).

Populasi penelitian adalah perusahaan asuransi yang sudah go public (tbk) sebagaimana juga digunakan pada penelitian sebelumnya (2011), dan masih tercatat pada Bursa Efek Indonesia pada saat penelitian dilakukan (2013). Fakta menunjukan hanya terdapat 9 perusahaan baik perusahaan nasional murni maupun perusahaan nasional yang berafiliasi. Mengingat jumlah perusahaanya yang menjadi objek penelitian relatif sedikit, sementara ketersediaan datanya sangat lengkap dan mudah didapatkan, maka diputuskan untuk mengambil semuanya sebagai objek penelitian. Dengan demikian jumlah sampel sama dengan populasi.

\section{Objek Penelitian dan Operasinalisasi Variabel Penelitian}

Objek dalam penelitian ini adalah 9 perusahaan asuransi nasional yang bersifat terbuka (Tbk) yang datanya berupa laporan keuangan dipublikasikan pada website Bursa Efek Indonesia (www.idx.go.id). Sembilan perusahaan itu adalah: (1) Asuransi Bina Dana Arta Tbk (ABDA), (2) Asuransi Harta Aman Pratama Tbk (AHAP), (3) Asuransi Bintang Tbk (ASBI), (4) Asuransi Dayin Mitra Tbk (ASDM), (5) Asuransi Multi Artha Guna Tbk (AMAG), (6) Asuransi Jasa Tania Tbk (ASJT), (7) Asuransi Ramayana Tbk (ASRM), (8) Panin Insurance Tbk (PNIN), (9) Lippo General Insurance Tbk (LPGI).

Berdasarkan penelitian sebelumnya, diketahui dua variabel exogen dalam penelitian yang ditentukan sesuai kajian teoretis. Yang pertama adalah variabel Strategi Efektivitas (STRAEFEK) yang terdiri dari variabel strategi pasar dan strategi penghematan. Yang kedua adalah Strategi Efisiensi (STRATEFIS) yang terdiri atas strategi produk, strategi manajemen dan sistem, strategi teknologi, dan strategi operasi. Kinerja perushaan terdiri dari rasio hutang terhadap aset (DAR), rasio modal terhadap aset (DER), Return on Asset (ROA), Return on Equity (ROE), Operating Profit Margin (OPM), dan Net Profit Margin (NPM). Tabel 1 menjelaskan

Tabel 1 Operasional Variabel Penelitian

\begin{tabular}{|c|c|c|}
\hline No. & Variabel Exogen sebagai variabel Independen & Indikator \\
\hline 01 & STRATEGI EFEKTIVITAS & $\begin{array}{l}\text { Strategi pasar } \\
\text { Strategi Penghematan }\end{array}$ \\
\hline 02 & STRATEGI EFISIENSI & $\begin{array}{l}\text { Strategi produk } \\
\text { Strategi manajemen dan system } \\
\text { Strategi teknologi } \\
\text { Strategi Operasi }\end{array}$ \\
\hline \multicolumn{3}{|c|}{ Variabel Endogen Variabel Dependen } \\
\hline 01 & $\begin{array}{l}\text { Variabel ratio keuangan antara hutang dan equitas terhadap } \\
\text { modal }\end{array}$ & $\begin{array}{l}\text { DAR } \\
\text { DER }\end{array}$ \\
\hline 02 & $\begin{array}{l}\text { Variabel ratio keuangan antara return terhadap hutang dan } \\
\text { equitas }\end{array}$ & $\begin{array}{l}\text { ROA } \\
\text { ROE }\end{array}$ \\
\hline 03 & Variabel ratio profitabilitas & $\begin{array}{l}\text { OPM } \\
\text { NPM }\end{array}$ \\
\hline
\end{tabular}




\section{Sumber dan Analisis Data}

Sumber data utama yang digunakan dalam penelitian ini adalah data sekunder yang berasal dari beberapa laporan keuangan perusahaan asuransi di Indonesia yang sudah go public (tbk) yang terpilih sebagai sampel. Data yang dianalisis merupakan data panel dengan runut waktu antara 2007 hingga 2012 berdasarkan 9 perusahaan asuransi yang sudah terdaftar pada perdagangan saham di Bursa Efek Indonesia. Data yang dianalisis terdiri dari dua sumber, yaitu data yang berasal dari analisis sebelumnya (data tentang strategi pemasaran) dan data yang dikumpulkan pada saat penelitian ini dilakukaan (data tentang nilai rasio keuangan perusahaan).

Analisis data yang utama menggunakan model statistik multivariate yaitu analisis interdependensi korelasi kanonikal. Teknik analisis ini dapat mengakomodasi variabel dependen lebih dari satu dalam bentuk data kontinu yang bersifat formatif. Untuk menyeleksi proses interdependensi variabel, kelayakan korelasional, dan analisis redundansi, analisis kausalitas Granger dan uji kointegrasi dilakukan. Untuk memudahkan semua proses analisis ini, penelitian menggunakan Excel 2010 dan StatistiXL dan Eviews 8.

\section{HASIL DAN PEMBAHASAN}

Sesuai dengan model awal yang dihasilkan dari penelitian sebelumnya, strategi efektifitas (STRAFEK) adalah fungsi dari $=0,264 X_{2}+0,235 X_{3}+0,251 X_{4}+0,260 X_{6}$. Sedangkan strategi efisiensi (STRAFIS) adalah fungsi dari $=0,576 X_{1}+0,578 X_{5}$. Keseluruhan variabel $\mathrm{x} 1$ hingga $\mathrm{x} 6$ nilainya dalam bentuk $\mathrm{Z}$ score. Agar setara, nilai variabel indikator keuangan pun diubah menjadi Zscore. Kemudian uji asumsi klasik dilakukan. Faktanya hasil uji tidak memenuhi syarat baik normalitas, homogenitas maupun linieritas. Untuk itu keseluruhan data ditransformasi menjadi nilai normal dengan teknik Blom's. Lalu terhadap keseluruhan data baik data independen maupun dependen dilakukan uji kelayakan untuk dianalisis yaitu uji normalitas, uji homogenitas, linieritas, dan stationaritas. Pengujian dilakukan untuk memastikan apakah data layak secara statistik dianalisis dengan model korelasi kanonik.

Langkah pertama adalah melakukan analisis deskriptif dan uji normalitas. Hasilnya adalah semua nilai koefisien probabilitas Jarque-Bera di atas 5\%. Secara statistik hal tersebut menunjukkan bahwa data telah terdistribusi secara normal. Langkah kedua adalah melakukan uji homogenitas dan linieritas. Hasil menunjukkan secara statistik data homogen dan data linier karena statistik uji menunjukkan semua di atas nilai alpha 5\%, sehingga layak untuk dianalisis dengan korelasi kanonik. Secara statistik variabel rata-rata strategi pemasaran berdistribusi normal, sedangkan kinerja keuangan hanya berdistribusi normal untuk alpha $1 \%$.

Hasil verifikasi dan analisis data telah diperoleh dengan menggunakan analisis korelasi kanonik. Dengan analisis ini ditemukan fakta bahwa dari dua kovariat yang terbentuk hanya 1 kovariat yang signifikan yaitu kovariat 1 (CV 1). Kovariat ini menghasilkan data sebagai berikut. Nilai korelasi sebesar 0,549 atau setara dengan 54,9\% pengaruh langsung antara strategi pemasaran perusahaan terhadap kinerja keuangan perusahaan atau sebaliknya. Meskipun faktanya hasil uji statistik dengan uji Granger Causality menunjukkan bahwa tidak ada satupun dari dua variabel yang dianalisis saling memengaruhi baik secara simultan maupun secara non recursive, hasil uji kointegrasi menunjukan bahwa kinerja keuangan perusahaan signifikan untuk menjelaskan strategi pemasaran. Hal ini bisa dijelaskan bahwa sesungguhnya strategi pemasaran perusahaan asuransi yang dianalisis ini tidaklah memberikan dampak terhadap kinerja keuangan. Akan tetapi, justru kinerja keuangan perusahaan yang memberikan dampak pada strategi pemasaran. 
Strategi efektivitas memberikan pengaruh langsung positif yang sangat besar pada strategi pemasaran perusahaan, sementara strategi efisiensi justru berdampak negatif. Artinya dalam strategi pemasaran, perusahaan harus mengurangi efisiensi dan meningkatkan efektivitas. Artinya perusahaan harus fokus pada bagaimana mengembangkan produk, teknologi, dan operasional agar bisa meningkatkan penerimaan premi perusahaan. Sementara strategi yang langsung berfokus pada bagaimana meningkatkan premi harus dihindari. Strategi peningkatan premi dalam jangka pendek hanya fokus pada penjualan namun tidak mempertahankan keberlangsungan pembayaran premi.

Hasil analisis redundansi korelasi kanonik menunjukkan bahwa pengaruh strategi pemasaran terhadap kinerja keuangan sebesar 15,5\% dan sebaliknya hanya sebesar 3\%. Dalam konteks matematis, strategi pemasaran yang lebih berdampak pada kinerja keuangan dibandingkan sebaliknya. Artinya secara langsung kinerja keuangan perusahaan baik yang bertujuan untuk meningkatkan aset dan penjualan menurunkan hutang dan kewajiban dipengaruhi keberhasilan pemasaran perusahaan. Dalam konteks bisnis jelas bahwa keberhasilan suatu perusahaan teruatama bidang asuransi bukan sekadar dari bagusnya pemasaran, melainkan juga kemampuan keuangan yang dimiliki.

Meskipun hanya 3\% pengaruh kinerja keuangan terhadap strategi pemasaran perusahaan, secara statistik itu adalah faktanya. Artinya kemampuan perusahaan mendapatkan premi yang besar sementara pembayaran klaim yang rendah menyebabkan keuntungan perusahaan meningkat. Ini dapat digunakan untuk memperbesar dan meningkatkan kinerja keuangan, sehingga akan menjadi promo yang riil pada konsumen atau nasabah tentang kekuatan pendanaan perusahaan.

Secara umum, strategi efektivitas pemasaran tidak signifikan terhadap DAR, DER dan ROE, sedangkan strategi efisiensi tidak signifikan terhadap DAR, DER dan NPM. Dengan demikian perusahaan harus berupaya untuk meningkatkan kinerja keuangan khusus untuk DAR dan DER tanpa mengandalkan strategi pemasaran. Sedangkan strategi efektivitas bagus untuk meningkatkan NPM namun strategi efisiensi tidak cocok. Sementara itu, strategi efisiensi cocok untuk meningkatkan ROE namun tidak halnya dengan strategi efektivitas.

\section{SIMPULAN}

Berdasarkan hasil olah data dan analisis, maka dapat disimpulkan secara statistik sebagai berikut. Pertama, terdapat hubungan yang relatif cukup antara variabel kanonik strategi pemasaran terhadap variabel kanonik kinerja keuangan. Kedua, tidak terdapat hubungan yang simultan antara variabel kanonik strategi pasar dengan variabel kanonik kinerja keuangan namun dapat dihitung nilai redundansi sebesar 15,5\% untuk pengaruh variabel kanonik strategi pemasaran terhadap variabel kanonik kinerja keuangan sedangkan sebaliknya, hanya 3\%. Secara nyata pengaruh sebesar 3\% inilah yang signifikan secara statistik.

\section{Saran}

Secara umum hasil analisis menunjukan secara statistik bahwa sesungguhnya strategi pemasaran memiliki pengaruh yang relatif cukup kuat untuk meningkatkan kinerja keuangan. Oleh karena itu peningkatan kemampuan pemasaran melalui pengembangan strategi pemasaran harus selalu giat dilakukan terutama pengembangan strategi efektivitas yang memberikan pengaruh positif terhadap keseluruhan strategi pemasaran. Karena strategi efektivitas dan strategi efisiensi tidak signifikan terhadap peningkatan kinerja DAR dan DER, sangat disarankan perusahaan tidak menggunakan strategi pemasaran untuk meningkatkan DAR, DER, ROE, dan NPM. Perusahaan disarankan berfokus saja pada bagaimana mengelola hutang dan modalnya, misalkan memperkuat portofolio di danareksa atau saham bluechips. 
Hasil analisis juga menunjukkan bahwa tidak terdapat simultaneus antara variabel kanonik yang diteliti. Hal ini menjelaskan bahwa ada variabel lain yang menjadikan perusahaan asuransi ini bisa bertahan dalam bisnisnya selain persoalan pemasaran. Oleh karena itu, yang sudah dilakukan oleh perusahaan selama ini harus tetap dipertahankan dan bahkan ditingkatkan sambil memerhatikan hasil penelitian ini. Meskipun tidak perlu fokus terhadap strategi pemasaran yang ditawarkan namun tetap dikerjakan dengan sebaik-baiknya.

\section{DAFTAR PUSTAKA}

Hopper, T. (2006). Marketing Strategy, Organisational Strategy and Organisational Performance: A study of Queensland's Hospitals. Australia: School of Management and Marketing, University of Southern Queensland.

Jaakkola, M., et al. (2010). Strategic marketing and business performance: a study in three european 'engineering countries'. Industrial Marketing Management, 39(8), 1300-1310.

Jogiyanto, H.M. (2004). Metode Penelitian Bisnis. Yogyakarta: BPFE.

Koksal, M. H., \& Ozgul, E. (2007). The relationship between marketing strategies and performance in an economic crisis. Marketing Intelligence \& Planning, 25(4), 326-342.

Neill, S., \& Rose, G. M. (2006). The effect of strategic complexity on marketing strategy and organizational performance. University of Washington, Tacoma: Milgard School of Business.

Neuman, W. L. (2000). Social Research Methods, Qualitative and quantitative Approaches. Allyn \& Bacon. 